\title{
Olumlu Okul İklimi Oluşturmada Öğretmenin Rolünün İncelenmesi
}

\author{
Alper ŞAHIN \\ Necmettin Erbakan Üniversitesi \\ alprshin@gmail.com \\ ORCID ID: 0000-0002-8855-8732 \\ Zehra ATBAȘI \\ Necmettin Erbakan Üniversitesi \\ zehrasutcu@gmail.com \\ ORCID ID: 0000-0002-2758-1277
}

\begin{tabular}{lrr} 
Araştırma Makalesi & DOI: $10.31592 /$ aeusbed.742972 \\
\hline Geliş Tarihi: 26.05 .2020 & Revize Tarihi: 10.09 .2020 & Kabul Tarihi: 27.09 .2020
\end{tabular}

\section{Atıf Bilgisi}

Şahin, A. ve Atbaş1, Z. (2020). Olumlu okul iklimi oluşturmada öğretmenin rolünün incelenmesi. Ahi Evran Üniversitesi Sosyal Bilimler Enstitüsü Dergisi, 6(3), 672-689.

\section{ÖZ}

Bu araştırmada öğretmenlerin görev yaptıkları okulda olumlu okul iklimi konusundaki bakış açılarını açığa çıkarmak amaçlanmıştır. Araştırmada karma yöntem desenlerinden açımlayıcı sıralı desen kullanılmıştır. Araştırmanın çalışma grubunu 2019-2020 eğitim-öğretim yılında Kırşehir il merkezinde yer alan ilkokul, ortaokul ve liselerde görev yapan 107 öğretmen oluşturmaktadır. Araștırmanın nicel boyutunda "Okul İklimi Ölçeği" uygulanmış ve araştırmanın nitel boyutunda ise araştırmacılar tarafından geliştirilmiş yarı yapılandırılmış görüşme formu ile verilerin toplanması sağlanmıştır. Ölçekten elde edilen puanların cinsiyet değişkenine göre farklılığın tespit edilmesinde bağımsız gruplar için t-testi, öğretmenlerin girdiği kademe ve kıdeme göre farklılığın tespit edilmesinde tek yönlü varyans analizi (ANOVA) yapılmıştır. Bulgularda, öğretmenlerin okul iklimi puanlarının çalışmada yer alan tüm faktörlerinin cinsiyet değişkenine göre istatistiksel olarak anlamlı düzeyde bir farklılık göstermediği ve öğretmenlerin görev yaptığı kademeye göre tüm faktörlerde istatistiksel olarak anlamlı düzeyde bir farklılık gösterdiği saptanmıștır. Öğretmenlerin okullarda olumlu iklim oluşması için iletişim ve iş birliğinin, her düşünce ve fikre saygı duyularak, ihtiyaçlar, gereksinimler, sorunlar rahatça konuşularak, empati-karşıllklı anlayış, sevgi ve saygı çerçevesi içinde, yardımlaşarak ve paylaşılarak, öğretmen, öğrenci ve okul yöneticileri arasında sosyal etkinlik ve sosyal faaliyetlerin sürekli düzenlenerek olması gerektiği belirtilmiştir. Elde edilen sonuçlar çerçevesinde öğrencilerin ya da 4. sınıf öğretmen adaylarının okul iklimi hakkında bakış açıları araştırılabilir, sonuçlar bu verilerle karşılaştırılması önerilmektedir.

Anahtar Kelimeler: Olumlu okul iklimi, karma model, açımlayıcı sıralı desen, öğretmen rolü.

\section{Examining the Role of the Teacher in Creating a Positive School Climate}

\begin{abstract}
In this study, it was aimed to reveal the perspectives of the teachers about the positive school climate in the school where they work. Exploratory sequential pattern, one of the mixed method patterns, was used in the study. The study group of the research consists of 107 teachers working in primary, secondary and high schools in Kurşehir city center in the 2019-2020 academic year. In the quantitative dimension of the research, the "School Climate Scale" was applied, and in the qualitative dimension of the research, data was provided to collect with a semi-structured interview form developed by the researchers. T-test for independent groups in determining the difference according to the gender variable of the scores obtained from the scale and Oneway analysis of variance (ANOVA) was performed to determine of the difference according to the grade and seniority entered of teachers. In the findings, it was found that all the factors which take part in study of the school climate scores of the teachers did not show a statistically significant difference according to the gender variable, and there was a statistically significant difference in all the factors according to the grade that the teachers served. In order to establish a positive climate in schools of teachers, communication and cooperation is by respected every thought and idea; by requirement, needs, problems can be spoken easily; by helping and sharing within the framework of empathy-mutual understanding, love and respect; it was stated that social activities and social actions should be by continuous organized among teachers, students and school administrators. Within the framework of the obtained results, of the students or 4th grade teacher candidates can be investigated the perspectives about the school climate, and it is recommended to compare with these data the results.
\end{abstract}

Keywords: Positive school climate, mixed model, exploratory sequential pattern, teacher role. 


\section{Giriş}

Okullardaki beklentiler toplumdaki gereksinimlerin artmasıla birlikte daha üst düzeye ulaşmıştır. Bu beklentilerin çoğu, öğretmenlik mesleğinin geçtiğimiz yıllara göre önemli şekilde değişmesine yol açmıştır. Öğretmenlere verilen sorumluluklar son yıllarda giderek artmıştır. Öğretmenlerin bu sorumlulukları üstlenmesi, özerk hareket etmelerini, eğitim süreçlerinde daha fazla söz sahibi olmalarını ve daha fazla sorumluluk almalarını gerektirmiştir (Eurydice, 2019). Okullar ise, hem öğretim fonksiyonuyla evrensel bilgi birikiminin aktarımında, hem de eğitimin işlevleriyle toplumsal değerlerin aktarımında önemli roller üstlenmekte olan çocuklara önemli görevler yükleyen yapılardır. Bu yapılarla birlikte okulların görev yüklediği olumlu iklimin başarısının etkilemesinde, toplumun okullara yüklediği görevleri yerine getirmesinin önemli bir katk1 sağlayacağ1 düşünülmektedir (Şenel ve Buluç, 2016). Okuldaki iklim ile ilgili olarak kullanılan genel hava ve duygular, okullarda çalışan kişilerin doğrudan veya dolaylı bir şekilde yaratılan çalışma ortamını belirtmekte olup, okul üyelerinin ilişkilerinden ve davranışlarından meydana gelmektedir (Yılmaz ve Altınkurt, 2013). Her okulun kendine özgü bir ikliminin bulunması, okullardaki iklimin temelleri ve işlevleri bakımından benzerliklerinin olmasına katkı sağlamıştır. Okul ikliminin, okul içindeki ve okul dışındaki bireyler üzerinde bırakılan etkiler bakımından farklılaşması ise, okulların kendilerine özgü olan iklimlerindendir (Thomas, 1976).

Yönetici, öğretmen, öğrenci ve personel olumlu bir okul ikliminde kendilerini bireysel olarak değerli olduklarını hissederler. Okuldaki okul üyeleri, olumlu iklim yaratılmasına başarılı bir şekilde katkıda bulunurlar. Ayrıca okuldaki üyelerin bu iklimin oluşmasında ilgililik, sosyal gelişim, okulda dayanışma, iletişim, akademik gelişim ve katılım firsatları vardır (Gonder ve Hymes, 1994). Okuldaki bireylerin birbirlerine güven duyması, öğretmenlerin kendilerini işe adamış olmaları, işbirlikli olarak çalışmaları, öğretmenlerin birbirlerine karşılıklı saygıda bulunmaları ve yardımcı olmaları, öğretmenler ve yöneticiler birbirlerini desteklemeleri de okuldaki olumlu iklimin yaratılmasında rol oynayan bazı davranışlardır (Ellis, 1988). Ayrıca okulda sağlıklı ve olumlu iklimin kurulmasında katılım ve aile desteği de önemlidir (Özdemir, Sezgin, Şirin, Karip ve Erkan, 2010). Bununla birlikte okuldaki çalışanların performansının ve moralinin artması (Freiberg, 1998), okuldaki değişimlerin başarılı bir şekilde gerçekleşmesinin sağlanması da olumlu bir okul iklimi oluşturulmasına katkı sağlar (Bulach ve Malone, 1994). Bu yüzden okullarda olumlu iklim oluşturmak önemli bir yere sahiptir.

Şişman ve Turan (2004, s.142) etkili bir okul ikliminin temel kavramlarını aşağıdaki şekil 1'de belirtmiştir:

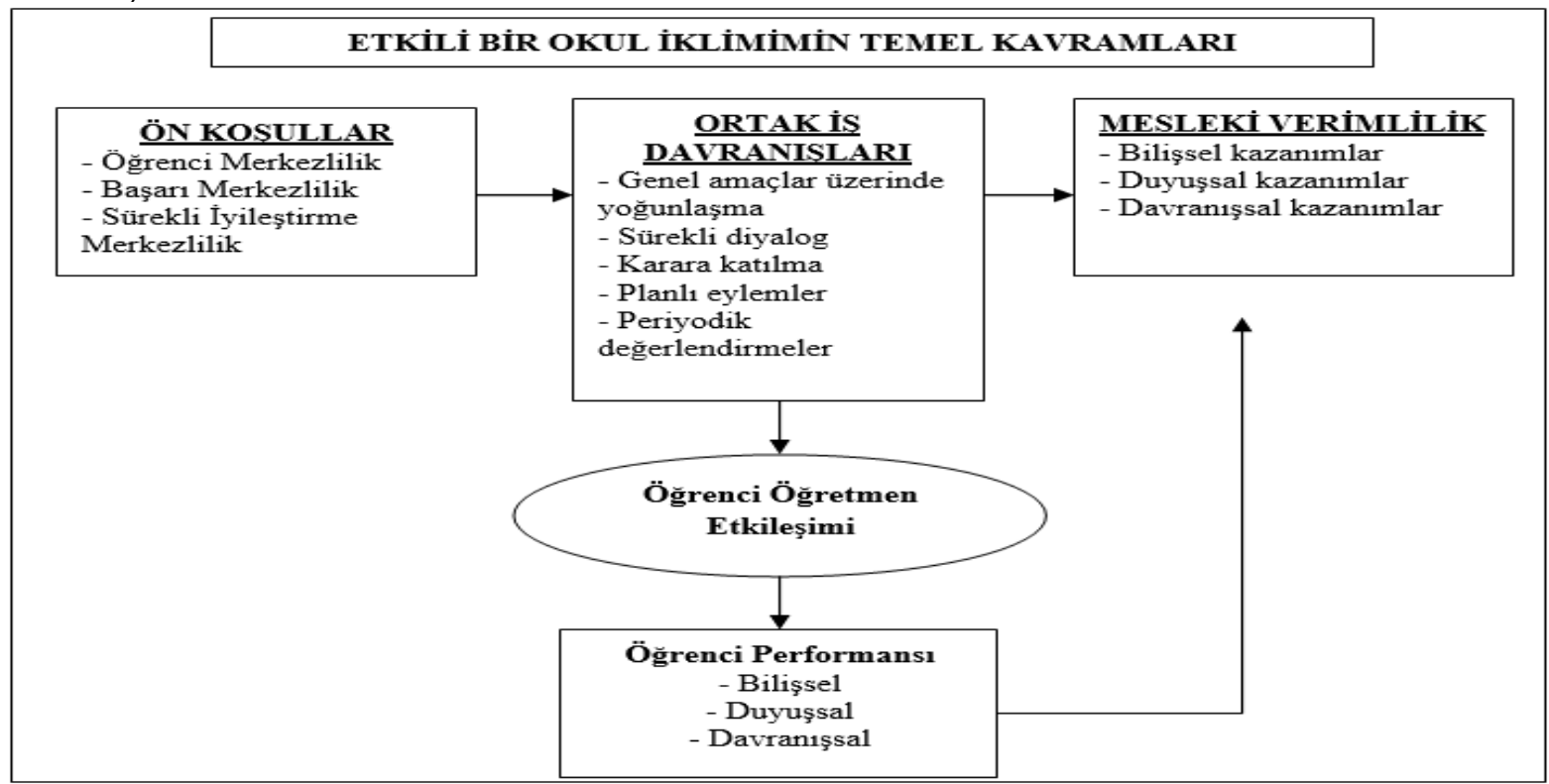

Şekil 1. Etkili Bir Okul İklimininin Temel Kavramları (Şişman, M. ve Turan, S. (2004). Eğitim ve okul yönetimi. İçinde Özden Y. (Ed.), Ĕ̆itim ve okul yöneticiliği el kitabı (ss. 99-159). Ankara: Pegem A.) 
Olumlu bir okul iklimi oluşturmada öğretmenlerin desteği hiç yadsınamaz bir gerçektir. Okul iklimi öğretmenlerin motivasyonunu olumlu yönde etkilediği için öğretmenlerin performans üzerinde büyük etkiye sahiptir. Öğretmenlerin yöneticilerle ve meslektaşlarıyla arasındaki ilişkiler derse olan davranışlarının ve motivasyonlarının şekillenmesinde önemli rol oynar (Hirase, 2000). Öğretmenler olumlu bir okul iklimi oluşturmada önemli bir rol oynar ancak uygulanan günlük stres ve taleplerin engeli bu süreci engelleyebilir. Öğretmenlerin, meslektaşlarıyla buluşmaları için problemlerini çözmek gerekir. Öğretmenler beceri geliştirme atölyelerine katılmak için okul idaresinden destek ve zamana ihtiyaç duyarlar. Destek grubu oturumları, öğretmenlerin yeni beceriler öğrenmelerine ve bunları sınıfta uygulamalarına yardımcı olabilir (Shapiro, Dupaul, Bradley ve Bailey, 1996). Öğretmenlerin derslerdeki bazı davranışları, ödül ve cezalandırma sistemleri, okuldaki çalışma grubunun yapısı okulun kültürel yapısını belirleyen ögeleri oluşturur (Celep, 2001).

Olumlu okul iklimine sahip okullar sağlıklı bir iklimin oluştuğu yerlerdir. Böyle bir okulda görev yapan öğretmenler, çoğunlukla öğrenciler için akademik başarıyı vurgularlar ve yine öğrenciler için etkili ve erişilebilir beklentiler koymalarına yardımcı olur. Okulda üretkenliğe sahip olan ögretmenler, birbirlerine karşı destekleyici, saygılı ve samimi bir ilişki içinde olurlar. Dolayısıyla yöneticiler de okuldaki diğer bireylerle mesleki ve olumlu anlamda destekleyici bir ilişki içindedir. Müdürler okula kaynakları sağladıklarında okul gelişimine katkıda bulunurlar. Bir okulda olumlu iklimin olması o okulun misyon duygusuna sahip olduğunu ve dış etkenlere karşı kendini koruduğunu açıkça söyler. Sağlıklı ve olumlu okul iklimi öğrenci başarısını olumlu anlamda artırır, morali en üst seviyeye çeker, çalışma ve olumlu öğrenme koşullarını üst düzeye çıkarır (Wei, 2003). Öğretmenlerin yöneticilerle ve birbirleriyle olan ilişkilerinin niteliği, okulda sağlıklı ve olumlu bir iklimin oluşmasında etkilidir. Olumlu bir okul iklimin oluşturulabilmesinde bu ilişkilerin niteliği, olumlu bir öğrenme ve öğretme ortamının da oluşmasına katkıda bulunur (Şişman ve Turan, 2004). Dolayısıyla olumlu bir okul ikliminin oluşmasında okuldaki yönetici ve öğretmenlerin büyük sorumluluğu vardır.

Olumlu bir okul ikliminin yaratılabilmesinde, okulun verimli ve etkin bir şekilde hedeflerine ulaşabilmesi, paylaşılmış değerlerlere sahip çıkılması, bu değerlerin sınırlı kaynakları ve yenilikleri etkili kullanmasına bağlıdır (Aytaç, 2000). Bir okulda başarıya değer veren, düzen ve disiplin öngören, yüksek performans sergileyen, işbirlikçi ilişkileri ön planda tutan ve etkili öğrenimi teşvik eden bir kültürün öğretmen tarafından oluşturulması gerekir. Burada öğretmenlere büyük görev düşmektedir. $\mathrm{Bu}$ değerlerin öğretilmesinde ise olumlu bir iklim oluşturmanın çok büyük bir önemi vardır. Olumlu iklim oluşturmada öğretmenlerin en büyük görevlerinden biri olması beklenebilir.

Okulun olumlu bir sosyal iklime sahip olmasının, öğrencilerin okula yönelik olumlu tutum geliştirmelerinde çok önemli bir katkısı vardır. Okul iklimindeki olumlu tutumlar, akademik gelişmenin ve öğrenme amaçlarının önem kazanmasına, okuldaki öğrencilerin saygı kapsamında birbirleriyle olumlu ilişkiler kurmasına, okuldaki ödül ceza sisteminin tutarlı, adaletli ve kararlı bir biçimde uygulanmasına, okuldaki öğrencilerin ailelerinin katılımının ve desteğinin kuvvetli bir şekilde sağlanmasına katkıda bulunur. Dolayısıyla öğrencilerin, öğrenme, risk alma ve güvenlik duygusu gibi bazı özelliklerini olumlu ya da olumsuz olarak etkileyen faktör okul iklimidir. Bu nedenle, öğrencilerin okula bağlılık göstermesi, okuldan memnuniyet duyması olumlu okul iklimiyle ilişkilidir (Özdemir, Sezgin, Şirin, Karip ve Erkan, 2010).Ayrıca, okulun olumlu bir okul iklime sahip olmasıögrencilerin ya da bireylerin eleştirel düşünme becerisi ve bilgi birikimine okumayla katkı sağlayacağı düşünülebilir (Duran ve Erkek, 2018).

Alanyazı incelendiğinde okullarda okul iklimi ile ilgili öğretmenler ve öğrenciler açısından araştırmalar yapılmıştır. Demir (2008) tarafından yapılan çalışmada, okullarda görev yapan öğretmenlerin performansı ile ortaöğretim okullarındaki okul iklimi arasındaki ilişki ele alınmış ve bu ilişkinin öğrencilerin bazı alt boyutlardaki algılanma düzeyleri incelenmiş, çalışma sonucunda ise, cinsiyet, yaş grubu, okul türü, eğitim alanı, sınıf, aile gelir düzeyi ve okul imkânları değişkenlerinde okul iklimi ve öğretmen performansı ile ilgili verilen cevaplarda anlamlı bir farklılık saptanmıştır. Bu nedenle, öğretmenlerin performans düzeyi üzerinde orta öğretim okullarındaki okul ikliminin önemli ölçüde etkili olduğu görülmüştür. Akman (2010) tarafindan yapılan yine benzer bir araştırmada, ilköğretim 6., 7. ve 8. sınıf öğrencilerinin şiddet ve okul iklimi algılarını bazı değişkenler açısından 
incelenmiş ve bu değişkenler arasındaki ilişkiyi tespit etmek amacıyla yapılmış, araştırmanın sonucunda, ilköğretim 6., 7. ve 8. sınıf öğrencilerinin okul iklimi genel algısında, anne eğitim düzeyi, sınıf düzeyi ve cinsiyet gibi etkenler açısından anlamlı farklılıklar olduğu görülmüş; baba eğitim düzeyi, aile gelir düzeyi ve aile birey sayısı değişenleri açısından ise bir farklılık olmadığ1 görülmüştür. Ulusal ve uluslararası alanyazında olumlu okul iklimi ile ilgili çok fazla çalışma yapılmadığı gözlenmiş̧tir (Durmuş, Aypay ve Aybek, 2017; Gray, Wilcox ve Nordstokke, 2017). Ancak uluslararası alanyazında okul iklimi ile ilgili çalışmaların olduğu görülmüştür (Wang ve Degol, 2016; Zullig, Koopman, Patton ve Ubbes, 2010; Way, Reddy ve Rhodes, 2007; Thapa, Cohen, Guffey ve Higgins-D’Alessandro, 2013; Bradshaw, Koth, Thornton ve Leaf, 2009). Bu yüzden araştırmada, öğretmenlerin olumlu okul iklim olşuturulmasında nasıl bir role sahip olacağı ve olumlu okul iklimi konusunda alanyazına kaynak sağlaması bakımından önemlidir. Buna ek olarak ulusal alanyazında öğretmenlerin olumlu okul iklimi ile ilgili az çalışma olduğu görülmüştür. Bu yüzden alanyazına katkı sağlayacağı bakımından da önemlidir.

Okullarda öğretmenlere çok büyük görev düştüğü ancak okullarda öğretmenlerin olumlu bir iklim yaratmasında hem ortak bir görüşe sahip olmadıkları hem de zorluklar yaşadığ gözlemlenmiştir. $\mathrm{Bu}$ yüzden, bu araştırmanın amacı öğretmenlerin görev yaptıkları okulda olumlu okul iklimi konusundaki bakış açılarını açığa çıkarmaktır. Bu sebeple bu çalışmada aşağıdaki sorulara yanıt aranmıştır:

1. Öğretmenlerin olumlu okul iklimi ile ilgili bakış açılarının,

a. Cinsiyete,

b. Kademeye,

c. Kıdeme göre anlamlı bir farkl11ık göstermekte midir?

2. Öğretmenlerin olumlu okul iklimine yönelik görüşleri nelerdir?

\section{Yöntem}

\section{Araştırmanın Deseni}

Öğretmenlerin görev yaptıkları okulda olumlu okul iklimi konusundaki bakış açılarını belirleyen bu araştırmada, öncelikle nicel yöntemin kullanıldığı, ardından daha özel sonuçlar aramak ve sonuçları daha derin yorumlamak için nitel yöntemin de yer aldığ 1 açımlayıcı karma desen kullanılmıştır. Genel olarak karma yöntem, gerek nicel gerek nitel veri toplama ve analiz süreçlerinin kullanılmasıyla ortaya çıkan, tek bir araştırmaya yönelik araştırma problemini anlama şeklinde belirtilmektedir (Creswell, 2005). Açımlayıcı karma desen ise, öncelikle nicel çalışmaların yürütülüp sonuçların analiz edilmesi ve sonrasında nicel verilerin desteklenmesi için de nitel verilerle daha detaylı açıklamak amacıyla yararlanılan desen olarak tanımlanmaktadır (Delice, 2015). Bu araştırmada ilk üç araştırma sorusundaki veriler nicel yöntemlerle toplanırken; son sorudaki bulgular nitel yöntemlerle elde edilmiştir.

\section{Çalıșma Grubu}

Araştırmanın çalışma grubunu 2019-2020 eğitim-öğretim yılının ilk yarıyılında Kırşehir il merkezindeki ilkokulda, ortaokulda ve lisede görev yapan 107 öğretmen oluşturmaktadır. Çalışma grubunu oluşturan öğretmenlerin cinsiyetinin, kıdeme ve kademe durumlarına göre dağılımlarına ilişkin betimsel istatistikler tablo 1'de gösterilmiştir. 
Tablo 1

Öğretmenlerin Cinsiyetinin Kıdem ve Kademe Durumuna Göre Dă̆ıllımı

\begin{tabular}{|c|c|c|c|c|c|c|c|}
\hline \multirow{2}{*}{\multicolumn{2}{|c|}{ Değişken }} & \multicolumn{5}{|c|}{ Kidem } & \multirow[b]{2}{*}{ Toplam } \\
\hline & & $1-5 \mathrm{y} 1 \mathrm{l}$ & 6-10 y1l & 11-15 y1l & $16-20$ y1l & $\begin{array}{c}21 \text { yıl ve } \\
\text { üzeri }\end{array}$ & \\
\hline \multirow{2}{*}{ Cinsiyet } & Kadın & 4 & 4 & 10 & 14 & 15 & 47 \\
\hline & Erkek & 1 & 2 & 8 & 14 & 35 & 60 \\
\hline \multicolumn{2}{|c|}{ Toplam } & 5 & 6 & 18 & 28 & 50 & 107 \\
\hline \multirow{2}{*}{\multicolumn{2}{|c|}{ Değişken }} & \multicolumn{5}{|c|}{ Kademe } & \multirow{2}{*}{ Toplam } \\
\hline & & İlkc & & Ortaokul & & Lise & \\
\hline \multirow{2}{*}{ Cinsiyet } & Kadın & & & 27 & & 1 & 47 \\
\hline & Erkek & & & 17 & & 5 & 60 \\
\hline \multicolumn{2}{|c|}{ Toplam } & \multicolumn{2}{|c|}{57} & 44 & \multicolumn{2}{|r|}{6} & 107 \\
\hline
\end{tabular}

Tablo 1 incelendiğinde, araştırmaya katılan kadın öğretmenlerin 4'ü 1-5 yıl arası ve 6-10 yıl arası kıdeme sahipken, 15'i 21 yıl üzeri kıdeme sahiptir. Ayrıca çalışma grubundaki erkek öğretmenlerin 1'i 1-5 yıl arası kıdeme sahipken, 14'ü 16-20 yıl arası kıdeme sahiptir. Araştırmadaki kadın öğretmenlerden 1'i lisede çalışırken, 19'u ilkokulda çalışmaktadır. Bunun yanı sıra erkek öğretmenlerden 5'i lisede çalışırken, 17'si ortaokulda, 38'i ilkokulda çalışmaktadır.

Araştırmanın nitel boyutunda daha özel sonuçları aramak ve bunları daha derin yorumlamak için 17 öğretmen ile görüşmeler gerçekleştirilmiştir. Araştırmanın nitel boyutunda basit seçkisiz örnekleme yöntemi kullanılmıştır. Basit seçkisiz örnekleme yöntemi, bir bireyin seçiminin diğeri bireylerin seçimini etkilemediği ve örneklem yönteminde tüm bireylerin seçilme olasılığının aynı olduğu için bu örnekleme yöntemine gidilmiştir (Büyüköztürk, Çakmak, Akgün, Karadeniz ve Demirel, 2014).

\section{Veri Toplama Araçları}

Araştırmanın nicel boyutunda Canlı, Demirtaş ve Özer (2018) tarafından geliştirilen "Okul İklimi Ölçeği” uygulanmıştır. Bu araştırmanın nitel boyutunda ise araştırmacılar tarafından geliştirilmiş "yarı yapılandırılmış görüşme formu” ile verilerin toplanması sağlanmıştır.

Bu çalışmada, Canlı, Demirtaş ve Özer (2018) tarafından geliştirilen Okul İklimi Ölçeği uygulanmıştır. Araştırmacılar tarafindan bu ölçeğin beş faktörlü bir yapıda olduğu ve toplam 23 maddeden oluştuğu ortaya konulmuştur. Bu boyutlar liderlik ve etkileşim, demokratiklik ve okula adanma, samimiyet, başarı etkenleri ve çatışma boyutu faktörlerinde ele alınmıştır. Bu ölçeğin 23 maddesi sırasıyla "her zaman, çoğunlukla, bazen, nadiren ve hiçbir zaman" şeklinde 5'li likert tipindedir. Bu araştırmanın geçerlik ve güvenirlik çalışması araştırmacılar tarafından yapılmış olup, Cronbach Alpha güvenirlik katsayısı liderlik ve etkileşim boyutunda ".90", demokratiklik ve okula adanma boyutunda ".91", samimiyet boyutunda ".85", başarı etkenleri boyutunda ".75" ve çatışma boyutunda “.73" olarak saptanmıştır.

$\mathrm{Bu}$ araştırmada ise ölçeğin Cronbach Alpha güvenirlik katsayısı 0,85 olarak hesaplanmıştır. Ölçeğin alt boyutları incelendiğinde, liderlik ve etkileşim boyutunda ".74", demokratiklik ve okula adanma boyutunda “.74", samimiyet boyutunda “.79”, başarı etkenleri boyutunda “.77” ve çatışma boyutunda ".78" olarak saptanmıştır.

$\mathrm{Bu}$ araştırmanın yarı yapılandırılmış görüşme formu 5 soru içermektedir. $\mathrm{Bu}$ araştırma sürecinde daha ayrıntılı bilgiye ulaşmak amacıyla yarı yapılandırılmış görüşme yapılmıştır. Yarı yapılandırılmış görüşme formunun kapsam geçerliliğini sağlamak amaciyla uzman görüşlerine 
başvurulmuş ve uzmanların önerileri doğrultusunda yarı yapılandırılmış görüşme formuna son şekli verilmiştir.

Yarı yapılandırılmış görüşme formunda aşağıdaki sorulara yer verilmiştir:

- Okullarda olumlu iklimin oluşması eğitim ortamına ve öğrencilere nasıl bir yarar sağlar?

- Okullarda olumlu okul iklimi oluşturulabilmesi için öğretmen davranışları nasıl olmalıdır?

- Okullarda olumlu okul iklimi geliştirebilmek için nelere dikkat edilmelidir?

- Okullarda olumlu bir okul iklimi geliştirilmesinde müdür-öğretmen ilişkisi ve öğretmenöğrenci ilişkisi nasıl olmalıdır?

- Okullarda olumlu iklim oluşturmada iletişim ve işbirliği nasıl sağlanır?

$\mathrm{Bu}$ araştırmanın verileri 2019-2020 eğitim-öğretim yılının ilk yarıyılında Kırşehir il merkezindeki ilkokul, ortaokul ve lisede görev yapan öğretmenler tarafından elde edilmiştir. $\mathrm{Bu}$ yüzden etik kurulu raporu istenmemiştir.

\section{Verilerin Analizi}

Nicel verilerin analizi araştırmanın birinci aşamasında gerçekleştirilmiştir. Uç ve kayıp değer analizleri verileri analiz edilmesinden önce yapılmıștır. Verilerin normal dağılıma uygun olup olmadığı ile ilgili olarak basıklık ve çarpıklık katsayıları analiz edilmiştir. Verilerin normal dağılım gösterdiği saptanmıştır. Birinci araştırma sorusunda, cinsiyet değişkenine göre farklılığın tespit edilmesinde bağımsız gruplar için t-testi kullanılmıştır. İkinci ve üçüncü araştırma sorularında, öğretmenlerin girdiği kademe ve kıdeme göre farklılığın tespit edilmesinde tek yönlü varyans analizi (ANOVA) yapılmıştır.

Araştırmanın ikinci aşamasında okul iklimine ilişkin daha fazla bilgi toplamak amacıyla nicel analizlerin sonunda elde edilen verilere dayalı olarak, yapılandırılmış görüşme sorularının analizi yapılmıştır. Bu görüşmelerden elde edilen verilerin öncelikle dökümü yapılmış; sonrasında ise veriler betimsel analiz ile çözümlenmiştir. Bu yaklaşıma göre veriler özetlenmiş ve yorumlanmıştır.

\section{Bulgular}

$\mathrm{Bu}$ bölümde "Okul İklimi Ölçeği” ve “yarı yapılandırılmış görüşme formu”nun uygulanmasından elde edilen bulgulara yer verilmiştir.

\section{Nicel Analizlere Ait Bulgular}

Cinsiyete göre, okul iklimi ölçeğindeki faktörlere yönelik bağımsız örneklemler $\mathrm{t}$ testi sonuçları tablo 2'de gösterilmiştir.

Tablo 2

Okul iklimi Ölçeğindeki Faktörlerin Puanlarının Cinsiyete Göre t-testi Sonuçları

\begin{tabular}{|c|c|c|c|c|c|c|c|}
\hline Faktörler & Cinsiyet & $N$ & $\bar{x}$ & Ss & $s d$ & $t$ & $p$ \\
\hline \multirow{2}{*}{$\begin{array}{l}\text { Demokratiklik ve Okula } \\
\text { Adanma }\end{array}$} & Kadın & 47 & 25,17 & 3,51 & \multirow[t]{2}{*}{105} & \multirow[t]{2}{*}{.538} & \multirow[t]{2}{*}{.592} \\
\hline & Erkek & 60 & 25,56 & 3,98 & & & \\
\hline \multirow{2}{*}{ Liderlik ve Etkileşim } & Kadın & 47 & 24,82 & 4,05 & \multirow[t]{2}{*}{105} & \multirow[t]{2}{*}{.491} & \multirow[t]{2}{*}{.624} \\
\hline & Erkek & 60 & 24,43 & 4,21 & & & \\
\hline \multirow{2}{*}{ Başarı Etkenleri } & Kadın & 47 & 17,08 & 2,20 & \multirow[t]{2}{*}{105} & \multirow[t]{2}{*}{.109} & \multirow[t]{2}{*}{.914} \\
\hline & Erkek & 60 & 17,03 & 2,61 & & & \\
\hline \multirow{2}{*}{ Samimiyet } & Kadın & 47 & 12,00 & 2,06 & \multirow[t]{2}{*}{105} & \multirow[t]{2}{*}{.536} & \multirow[t]{2}{*}{.593} \\
\hline & Erkek & 60 & 12,21 & 2,08 & & & \\
\hline \multirow{2}{*}{ Çatışma } & Kadın & 47 & 14,91 & 2,63 & \multirow[t]{2}{*}{105} & \multirow[t]{2}{*}{.453} & \multirow[t]{2}{*}{.651} \\
\hline & Erkek & 60 & 14,60 & 4,48 & & & \\
\hline
\end{tabular}


Tablo 2'de görüldüğ̈̈ gibi, çalışma örneklemindeki öğretmenlerin okul iklimi ölçeğinin liderlik ve etkileşim $\left(\mathrm{t}_{(105)}=.491, \mathrm{p}>.05\right)$, demokratiklik ve okula adanma $\left(\mathrm{t}_{(105)}=.538, \mathrm{p}>.05\right)$, samimiyet $\left(\mathrm{t}_{(105)}=.536, \mathrm{p}>.05\right)$, başarı etkenleri $\left(\mathrm{t}_{(105)}=.109, \mathrm{p}>.05\right)$ ve çatışma $\left(\mathrm{t}_{(105)}=.453, \mathrm{p}>.05\right)$ alt faktörlerinden aldıkları puanların cinsiyet değişkenine göre istatistiksel olarak anlamlı düzeyde bir farklılık göstermediği görülmüştür. Erkek öğretmenlerin demokratiklik ve okula adanma alt faktöründen aldıkları puanın $(\overline{\mathrm{X}}=25,56)$ ve samimiyet alt faktöründen aldıkları puanın $(\overline{\mathrm{X}}=12,21)$; kadın öğretmenlerin demokratiklik ve okula adanma alt faktöründen aldıkları puandan $(\bar{X}=25,17)$ ve samimiyet alt faktöründen aldıkları puandan $(\overline{\mathrm{X}}=12,00)$ daha yüksek olduğu belirlenmiştir. Kadın öğretmenlerin liderlik ve etkileşim alt faktöründen aldıkları puanın $(\overline{\mathrm{X}}=24,82)$, başarı etkenleri alt faktöründen aldıkları puanın $(\overline{\mathrm{X}}=17,08)$ ve çatışma alt faktöründen aldıkları puanın $(\overline{\mathrm{X}}=14,91)$; erkek öğretmenlerin liderlik ve etkileşim alt faktöründen aldıkları puandan $(\bar{X}=24,43)$, başarı etkenleri alt faktöründen aldıkları puandan $(\bar{X}=17,03)$ ve çatışma alt faktöründen aldıkları puandan $(\bar{X}=14,60)$ daha yüksek olduğu belirlenmiştir.

Öğretmenlerin görev yaptıkları kademeye (ilkokul, ortaokul ve lise) göre okul iklimi ölçeği alt faktörlerinden aldıkları puanların betimsel istatistik değerleri, aldıkları bu puanlar arasında anlamlı farkın olup olmadığını belirlemek amacıyla ilişkisiz örneklemler için tek yönlü varyans analizi (ANOVA), anlamlı ise anlamlı farkın hangi gruplar arasında olduğunu belirlemek üzere Scheffe testi yapılmış ve sonuçlar tablo 3 'te gösterilmiştir.

Tablo 3

Öğretmenlerin Girdikleri Kademeye Göre Okul İklimi Ölçeği Alt Faktörlerinden Aldıkları Puanların Betimsel İstatistik Değerleri ve ANOVA Sonuçları

\begin{tabular}{|c|c|c|c|c|c|c|c|c|}
\hline Faktörler & & Kademe & $N$ & $\bar{x}$ & Ss & $F$ & $p$ & Anlamll fark \\
\hline \multirow{3}{*}{$\begin{array}{l}\text { Demokratiklik } \\
\text { Adanma }\end{array}$} & \multirow{3}{*}{ Okula } & İlkokul & 57 & 26,87 & 3,31 & \multirow{3}{*}{12,89} & \multirow{3}{*}{.000} & \multirow{3}{*}{ İ-O } \\
\hline & & Ortaokul & 44 & 23,40 & 3,28 & & & \\
\hline & & Lise & 6 & 25,83 & 5,11 & & & \\
\hline \multirow{3}{*}{\multicolumn{2}{|c|}{ Liderlik ve Etkileşim }} & İlkokul & 57 & 26,28 & 3,41 & \multirow{3}{*}{12,76} & \multirow{3}{*}{.000} & \multirow{3}{*}{ İ-O } \\
\hline & & Ortaokul & 44 & 22,50 & 3,80 & & & \\
\hline & & Lise & 6 & 24,16 & 5,91 & & & \\
\hline \multirow{3}{*}{\multicolumn{2}{|c|}{ Başarı Etkenleri }} & İlkokul & 57 & 18,19 & 1,91 & \multirow{3}{*}{22,06} & \multirow{3}{*}{.000} & \multirow{3}{*}{$\dot{\mathrm{I}}-\mathrm{O}$} \\
\hline & & Ortaokul & 44 & 15,47 & 2,19 & & & \\
\hline & & Lise & 6 & 17,83 & 2,40 & & & \\
\hline \multirow{3}{*}{\multicolumn{2}{|c|}{ Samimiyet }} & İlkokul & 57 & 12,87 & 1,90 & \multirow{3}{*}{9,44} & \multirow{3}{*}{.000} & \multirow{3}{*}{ İ-O } \\
\hline & & Ortaokul & 44 & 11,25 & 1,85 & & & \\
\hline & & Lise & 6 & 11,33 & 2,50 & & & \\
\hline \multirow{3}{*}{\multicolumn{2}{|c|}{ Çatışma }} & İlkokul & 57 & 15,75 & 3,99 & \multirow{3}{*}{5,99} & \multirow{3}{*}{.003} & \multirow{3}{*}{ İ-O } \\
\hline & & Ortaokul & 44 & 13,29 & 3,03 & & & \\
\hline & & Lise & 6 & 15,66 & 3,50 & & & \\
\hline
\end{tabular}

Tablo 3'teki analiz sonuçları incelendiğinde, çalışma örneklemindeki öğretmenlerin okul iklimi ölçeğinin liderlik ve etkileşim alt faktöründen aldıkları puanın $\left(\mathrm{F}_{(2-104)}=12,76, \mathrm{p}<.05\right)$, demokratiklik ve okula adanma alt faktöründen aldıkları puanın $\left(\mathrm{F}_{(2-104)}=12,89, \mathrm{p}<.05\right)$, samimiyet alt faktöründen aldıkları puanın $\left(\mathrm{F}_{(2-104)}=9,44, \mathrm{p}<.05\right)$, başarı etkenleri alt faktöründen aldıkları puanın $\left(\mathrm{F}_{(2-104)}=22,06, \mathrm{p}<.05\right)$ ve çatışma alt faktöründen aldıkları puanın $\left(\mathrm{F}_{(2-104)}=5,99, \mathrm{p}<.05\right)$ kademeye göre istatistiksel olarak anlamlı düzeyde bir farklılık olduğu saptanmıştır. Scheffe testi sonuçlarına göre, demokratiklik ve okula adanma alt faktöründe ilkokul $(\bar{X}=26,87)$ ile ortaokul $(\bar{X}=23,40)$ arasında ilkokul lehine; liderlik ve etkileşim alt faktöründe ilkokul $(\bar{X}=26,28)$ ile ortaokul $(\bar{X}=22,50)$ arasında ilkokul lehine; başarı etkenleri alt faktöründe ilkokul $(\overline{\mathrm{X}}=18,49)$ ile ortaokul $(\overline{\mathrm{X}}=15,47)$ arasında ilkokul lehine; samimiyet alt faktöründe ilkokul $(\overline{\mathrm{X}}=12,87)$ ile ortaokul $(\overline{\mathrm{X}}=11,25)$ arasında ilkokul lehine ve çatışma alt faktöründe ilkokul $(\overline{\mathrm{X}}=15,75)$ ile ortaokul $(\overline{\mathrm{X}}=13,29)$ arasında ilkokul lehine anlamlı düzeyde farkl1l1klar olduğu görülmüsstür.

Okul iklimi ölçeğindeki faktörlerden alınan puanların öğretmenlerin kıdemlerine (1-5 yıl, 6-10 yı1, 11-15 y1l, 16-20 yıl, 21 yıl ve üzeri) göre betimsel istatistik değerleri, aldıkları bu puanlar arasında 
anlamlı farkın olup olmadığını belirlemek amacıyla ilişkisiz örneklemler için tek yönlü varyans analizi (ANOVA), anlamlı ise anlamlı farkın hangi gruplar arasında olduğunu belirlemek üzere Scheffe testi yapılmış ve sonuçlar tablo 4 'te verilmiştir.

Tablo 4

Öğretmenlerin Kıdemlerine Göre Okul İklimi Ölçeği Alt Faktörlerinden Aldıkları Puanların Betimsel Istatistik Değerleri ve ANOVA Sonuçları

\begin{tabular}{|c|c|c|c|c|c|c|c|}
\hline Faktörler & Kidem & $N$ & $\bar{x}$ & Ss & $F$ & $p$ & $\begin{array}{c}\text { Anlaml } \\
\text { Fark }\end{array}$ \\
\hline \multirow{5}{*}{$\begin{array}{l}\text { Demokratiklik ve Okula } \\
\text { Adanma }\end{array}$} & $1-5 \mathrm{y} 11$ & 5 & 26,40 & 1,67 & \multirow{5}{*}{3,22} & \multirow{5}{*}{.016} & \multirow{5}{*}{$\begin{array}{c}16-20 \text { y1l, } \\
21 \text { yıl ve } \\
\text { üzeri }\end{array}$} \\
\hline & $6-10$ y1l & 6 & 25,17 & 2,32 & & & \\
\hline & $11-15 \mathrm{y} 1 \mathrm{l}$ & 18 & 24,94 & 3,21 & & & \\
\hline & $16-20$ y1l & 28 & 23,54 & 4,30 & & & \\
\hline & 21 y1l ve üzeri & 50 & 26,52 & 3,58 & & & \\
\hline \multirow{5}{*}{ Liderlik ve Etkileşim } & $1-5 \mathrm{y} 11$ & 5 & 27,60 & 2,88 & \multirow{5}{*}{6,54} & \multirow{5}{*}{.000} & \multirow{5}{*}{$\begin{array}{c}16-20 \text { y1l, } \\
21 \text { yıl ve } \\
\text { üzeri }\end{array}$} \\
\hline & $6-10$ y1l & 6 & 21,67 & 2,80 & & & \\
\hline & $11-15$ y1l & 18 & 23,50 & 3,49 & & & \\
\hline & $16-20 \mathrm{y} 11$ & 28 & 22,54 & 4,10 & & & \\
\hline & 21 yıl ve üzeri & 50 & 26,22 & 3,79 & & & \\
\hline \multirow{5}{*}{ Başarı Etkenleri } & $1-5$ y1l & 5 & 19,00 & 1,73 & \multirow{5}{*}{5,01} & \multirow{5}{*}{.001} & \multirow{5}{*}{$\begin{array}{c}16-20 \text { y1l, } \\
21 \text { yıl ve } \\
\text { üzeri }\end{array}$} \\
\hline & $6-10 y_{11}$ & 6 & 16,50 & 1,87 & & & \\
\hline & $11-15$ y1l & 18 & 16,67 & 1,88 & & & \\
\hline & $16-20$ y1l & 28 & 15,71 & 2,72 & & & \\
\hline & 21 yıl ve üzeri & 50 & 17,82 & 2,19 & & & \\
\hline \multirow{5}{*}{ Samimiyet } & $1-5 \mathrm{y} 11$ & 5 & 13,80 & 0,84 & \multirow{5}{*}{5,15} & \multirow{5}{*}{.001} & \multirow{5}{*}{$\begin{array}{c}16-20 \text { y1l, } \\
21 \text { yıl ve } \\
\text { üzeri }\end{array}$} \\
\hline & $6-10$ y1l & 6 & 10,83 & 1,33 & & & \\
\hline & $11-15$ y1l & 18 & 12,22 & 1,96 & & & \\
\hline & $16-20 \mathrm{y} 1 \mathrm{l}$ & 28 & 11,00 & 2,23 & & & \\
\hline & 21 yıl ve üzeri & 50 & 12,70 & 1,84 & & & \\
\hline \multirow{5}{*}{ Çatışma } & $1-5$ y1l & 5 & 15,40 & 1,14 & \multirow{5}{*}{2,22} & \multirow{5}{*}{.072} & \multirow{5}{*}{ YOK } \\
\hline & $6-10$ y1l & 6 & 14,00 & 1,41 & & & \\
\hline & $11-15 \mathrm{y} 11$ & 18 & 14,83 & 2,81 & & & \\
\hline & $16-20 y_{11}$ & 28 & 13,11 & 3,78 & & & \\
\hline & 21 yıl ve üzeri & 50 & 15,64 & 4,16 & & & \\
\hline
\end{tabular}

Tablo 4'te belirtildiği gibi, çalışma örneklemindeki öğretmenlerin okul iklimi ölçeğinin liderlik ve etkileşim alt faktöründen aldıkları puanın $\left(\mathrm{F}_{(4-102)}=6,54, \mathrm{p}<.05\right)$, demokratiklik ve okula adanma alt faktöründen aldıkları puanın $\left(\mathrm{F}_{(4-102)}=3,22, \mathrm{p}<.05\right)$, samimiyet alt faktöründen aldıkları puanın $\left(\mathrm{F}_{(4-102)}=5,15, \mathrm{p}<.05\right)$ ve başarı etkenleri alt faktöründen aldıkları puanın $\left(\mathrm{F}_{(4-102)}=5,01, \mathrm{p}<.05\right)$ öğretmenlerin kademelerine göre istatistiksel olarak anlamlı düzeyde bir farklılık olduğu saptanmıştır. Ancak çatışma alt faktöründen aldıkları puanın $\left(\mathrm{F}_{(4-102)}=5,15, \mathrm{p}<.05\right)$ kademeye göre istatistiksel olarak anlamlı düzeyde bir farklılık görülmediği belirlenmiştir. Scheffe testi sonuçlarına göre, demokratiklik ve okula adanma alt faktöründe 21 yıl ve üzeri $(\overline{\mathrm{X}}=26,52)$ ile $16-20$ yıl $(\overline{\mathrm{X}}=23,54)$ arasında " 21 yıl ve üzeri" lehine; liderlik ve etkileşim alt faktöründe 21 yıl ve üzeri $(\bar{X}=26,28)$ ile $16-20$ y1l $(\bar{X}=22,54)$ arasında "21 yıl ve üzeri" lehine; başarı etkenleri alt faktöründe 21 y1l ve üzeri $(\overline{\mathrm{X}}=17,82)$ ile $16-20$ yıl $(\overline{\mathrm{X}}=15,71)$ arasında " 21 yıl ve üzeri" lehine ve samimiyet alt faktöründe 21 y1l ve üzeri $(\overline{\mathrm{X}}=12,70)$ ile 16-20 yıl $(\overline{\mathrm{X}}=11,00)$ arasında "21 yıl ve üzeri” lehine anlamlı düzeyde farkl1lıklar olduğu görülmüştür.

\section{Nitel Analizlere Ait Bulgular}

Öğretmenler ile yapılan görüşmeden elde edilen verilerin analizi sonucunda öğretmenlerin okulda olumlu iklim oluşabilmesi için eğitim ortamına ya da öğrencilere nasıl bir yarar sağladığına dair görüşleri tablo 5 'te gösterilmişsir. 
Tablo 5

Öğretmenlerin Okullarda Olumlu İklim Oluşabilmesi Iç̧in Ĕgitim Ortamına ve Öğrencilere Sağladiğı Yararlar Hakkındaki Görüşleri

\begin{tabular}{ll}
\hline Alt temalar & Kodlar \\
\hline & Eğitimin amaçlarına ulaşması sürecine katkı sağlar. \\
& Olumlu bir ortamın oluşmasını sağlar. \\
& Öğrenmeyi kolaylaştırır ve daha kalıcı eğitim sağlar. \\
Eğitim ortamına & Ortak hedef, ortak davranış kültürü pekişir. \\
sağladığı katkılar & Eğitim-öğretim faaliyetlerini olumlu etkiler ve akademik başarıya doğrudan katkı \\
& sağlar. \\
& Öğretmen ve öğrencide karşılıklı olarak olumlu tavırlar geliştirilir. \\
& Çalışan paydaşlar arasında etkili iletişim sağlar. \\
& Öğretmenlerin performansının artmasına katkıda bulunur. \\
& Öğrenci ve öğretmenin motivasyonunu artırır, başarılı bir öğrenci gelişmesine katkıda \\
& bulunur. \\
& Öğrenciler kendini daha iyi hisseder. \\
& Öğrencinin eğitim faaliyetlerinde kendilerine, sınıfa ya da okula olan özgüveni artar. \\
& Öğrencinin derslere olan ilgisini ve alakasını artırır. \\
& Öğğrencinin derse olan verimliliği artar. \\
& Öğrencilerin olumlu yönde davranış geliştirmesini sağlar. \\
sağladığğ katkılar & Öğrencilerde öğrenme hevesini artırır. \\
& Öğrencilerin okula mutlu ve istekli bir şekilde gelmesini sağlar. \\
\hline &
\end{tabular}

Tablo 5’te görüldüğü gibi, okulda oluşan olumlu iklimin eğitim ortamına ve öğrencilere birçok açıdan katk1 sağladığ1 görülmüştür. Öğretmenlerin eğitim ortamına yönelik görüşleri; eğitimin amaçlarına ulaşmasında, olumlu bir ortamın oluşmasında, öğrenmeyi kolaylaştırmasına, daha kalıcı bir eğitim sağlamasına, ortak hedef, ortak davranış kültürünün pekiştirilmesinde, akademik başarıya doğrudan katkı sağlamasına, olumlu tavırlar gelişmesine, etkili iletişim sağlanmasına, öğretmenlerin performansının artmasına katkıda bulunur. Öğretmenlerin öğrencilere yönelik görüşleri; motivasyonun artmasına, başarılı bir öğrenci gelişmesine, öğrencilerin kendilerini daha iyi hissetmesine, özgüvenlerinin artmasına, derslere olan ilgisinin ve alakasının artmasına, verimliliğin artmasına, olumlu yönde davranış geliştirmesine, öğrenme hevesini artırmasına, öğrencilerin okula mutlu ve istekli bir şekilde gelmesini sağlamasına katkıda bulunur. Ayrıca öğretmenlerin görüşleri doğrultusunda, hem eğitim ortamına hem de öğrencilere sağladığı katkıların olumlu okul iklimi oluşturulmasında önemli olduğu çıkarılabilir.

Öğretmenler ile yapılan görüşmeden elde edilen verilerin analizi sonucunda okulda olumlu bir iklim oluşturulmasında öğretmen davranışlarının nasıl olması gerektiği konusundaki görüşleri tablo 6'da gösterilmiştir.

Tablo 6

Öğretmenlerinolumlu Bir İklim Oluşturulmasında Öğretmen Davranışlarının Nasıl Olması Gerektiğine Yönelik Görüşleri

\begin{tabular}{ll}
\hline Alt Temalar & Kodlar \\
\hline & Öğretmen hedef ve sorumluluklarının farkında olmalıdır. \\
& Hoşgörülü, bilimsel gelişmelere açık olmalıdır. Özellikle iletişim konusunda yeterli bilgi \\
& ve donanıma sahip olmalıdır. \\
& Denetimin artması ve okulun sevdirilmesi gerekmelidir. \\
Öğretmenlerin & Saydam, şeffaf ve saygınlık ilişkileri içerisinde olmalıdır. \\
kendilerine yönelik & Daha istekli olmalı ve çalışmalıdır. \\
& Öğretmenler arasında karşılıklı saygı ve sevgi olmalıdır. \\
& Herkese, her görüşe saygılı olmalıdır \\
& Diğer paydaşlarla ilişkisinin samimi ve eğitici olmalıdır. \\
& Öğgencilerin bireysel farklılıklarını keşfetmelidir. \\
& Öğrencilere uygun dille yaklaşılmalıdır. \\
& Öğgrencilere sıcak olmalı ve agresif davranmamalıdır. \\
Ögrencilere & Öğrenciler ile iletişimi açık ve net olmalıdır. \\
& Öğrencilere karşı herhangi bir olumsuz durumda saygılı olmalıdır. \\
\hline
\end{tabular}


Öğrencilere yaklaşımı olumlu olmalıdır.

Öğrencilere karşı demokratik ve hoşgörülü olması gerekir.

Öğrencilere karşı tüm davranışları ile rol model olmalıdır.

Tablo 6 incelendiğinde, öğretmenlerin okulda olumlu bir iklim oluşturulmasında öğretmen davranışlarının hem kendilerine yönelik hem de öğrencilere yönelik görüşleri belirtilmiştir. Kendilerine yönelik görüşlerinde; hedef ve sorumluluklarının farkında olmalı, hoşgörülü ve bilimsel gelişmelere açık olmalı, iletişim konusunda bilgi ve donanıma sahip olmalı, öğretmenlere okulun sevdirilmesi gerekmeli, saydam, şeffaf ve saygınlık ilişkileri içerisinde olmalı, daha istekli olmalı ve çalışmalıdır, öğretmenler arasında karşılıklı saygı ve sevgi olmalıdır, diğer paydaşlarla ilişkisi samimi ve eğitici olmalıdır. Öğrencilere yönelik görüşlerinde; öğrencilerin bireysel farklılıklarını keşfetmeli, öğrencilere uygun bir dille yaklaşılmalı, öğrencilere sıcak olmalı ve agresif davranmamalı, öğrenciler ile iletişimi açık ve net olmalı, öğrencilere karşı herhangi bir olumsuz durumda saygıll olmalı, öğrencilere yaklaşımı olumlu olmalı, öğrencilere karşı tüm davranışları ile rol model olmalı, öğrencilere karşı demokratik ve hoşgörülü olması gerekir.

Öğretmenler ile yapılan görüşmeden elde edilen verilerin analizi sonucunda öğretmenlerin okulda olumlu iklim oluşabilmesi için nelere dikkat edilmesi gerektiği konusundaki görüşleri tablo 7'de verilmiştir.

Tablo 7

Öğretmenlerin Okulda Olumlu İklim Oluşabilmesi Iç̧in Nelere Dikkat Edilmesi Gerektiğine Yönelik Görüşleri

\begin{tabular}{|c|c|}
\hline Alt Temalar & Kodlar \\
\hline \multirow{4}{*}{ İşbirliği } & $\begin{array}{l}\text { Müdür, öğretmen, öğrenci ve diğer okul personeli işbirliği içerisinde olmalıdır. Herkesin } \\
\text { sorumluluklarının farkında olmalıdır. }\end{array}$ \\
\hline & $\begin{array}{l}\text { Kurallara herkesin aynı derecede sahip çıkmasına, hoşgörünün temele alınmasına, ortak hedef } \\
\text { ve amaçların oluşturulmasına dikkat etmelidir. Bu kararlar alınırken okuldaki tüm paydaşların } \\
\text { fikirlerinin alınmasına dikkat edilmelidir. }\end{array}$ \\
\hline & $\begin{array}{l}\text { Öğretmen-veli, öğretmen-öğrenci, öğretmen-idare ve öğrenci-idare ilişkilerine dikkat } \\
\text { edilmelidir. }\end{array}$ \\
\hline & $\begin{array}{l}\text { Siyasi tartışmalardan uzak olmalı, sadece eğitimle ilgili konularda görüş alışverişi yapmak } \\
\text { gerekir. }\end{array}$ \\
\hline \multirow{6}{*}{ İletişim } & Öğretmen kendini her alanda geliştirip, öğrencilerine karşın saygılı olmalıdır. \\
\hline & Herkesin birbirine karşı iletişiminde saygı, sevgi ve hoşgörülü bir ortam sağlanmalıdır. \\
\hline & Müdür, müdür yardımcısı ve öğretmenler arasında karşılıklı iletişim ve davranışların hiyerarşi \\
\hline & içerisinde olmalıdır. \\
\hline & Okuldaki tüm paydaşlar birbirlerine saygılı olmalıdır. \\
\hline & Herkes birbirini dinlemelidir. \\
\hline
\end{tabular}

Tablo 7'de görüldüğü gibi, öğretmenlerin okulda olumlu iklim oluşabilmesi için nelere dikkat edilmesi gerektiğine yönelik görüşleri 2 alt tema belirlenmiştir. İşbirliği alt temasında, ilgili herkesin işbirliği içinde olması gerektiği ve herkesin sorumluluklarının farkında olması gerektiği, ilgili paydaşların kurallara aynı derecede sahip çıkmalı, hoşgörü temele alınmalı, ortak hedef ve amaçların oluşturulmasına dikkat edilmeli, ikili ilişkilere dikkat edilmelidir ve siyasi tartışmalardan uzak olunmalı ve sadece eğitimle ilgili görüş alışverişi yapılması gerektiği vurgulanmıştır. İletişim alt temasında ise, öğretmenin öğrencilere karşın saygılı olması gerektiği, karşılıklı iletişimde saygı, sevgi ve hoşgörülü bir ortam sağlanmalı, okuldaki tüm paydaşların karşılıklı iletişim ve davranışların hiyerarşi içerisinde olmalı, okuldaki tüm paydaşlar birbirleriyle saygılı olmalı, herkesin birbirini dinlemesi gerektiği vurgulanmıştır.

Öğretmenler ile yapılan görüşmeden elde edilen verilerin analizi sonucunda öğretmenlerin okulda olumlu iklim oluşturmada iletişim ve işbirliğini nasıl sağlaması gerektiğine yönelik görüşleri tablo 8'de gösterilmiştir. 
Tablo 8

Öğretmenlerin Okuldaolumlu İklim Oluşturmada İletişim ve İşbirliğini Nasıl Sağlaması Gerektiğine Yönelik Görüşleri

\begin{tabular}{|c|c|}
\hline Alt Temalar & Kodlar \\
\hline \multirow[b]{2}{*}{ İletişim } & $\begin{array}{l}\text { Konuşarak, anlayışla ve her düşünce ve fikre saygı duyularak sağlanır. } \\
\text { İtivaclar, gereksinimler, sorunlar rahatca konusulun cözz̈lmelidir. }\end{array}$ \\
\hline & $\begin{array}{l}\text { Empati-karşlıklı anlayıš, sevgi ve saygı çerçevesinde, yardımlaşma ve paylaşmayla sağlanır. } \\
\text { Alınan kararlarda birbirlerine saygı duyulmalıdır. Yenilikçi fikirlere açık olunmalıdır. } \\
\text { Öğrenci öğretmen ve veli arasında iletişim sağlam olmalıdır. }\end{array}$ \\
\hline \multirow{4}{*}{ İşbirliği } & $\begin{array}{l}\text { Öncelikle idare kaynaklı bir plan, program ve organize ile tertip edilmiş personel birbirinden } \\
\text { haberdar, yaratıcı ve eğitimi destekleyici bir işbirliği içinde olmalıdır. }\end{array}$ \\
\hline & Öğretmenler arasında yemek, çay vb. etkinliklerle birlikte olmaları sağlanılmalıdır. \\
\hline & Okul gecesi düzenlenmeli, sosyal faaliyet vb. düzenlenerek işbirliği içinde olması \\
\hline & $\begin{array}{l}\text { Yapılan toplantılarda, özel günlerde bir arada olunmalıdır ve alınan kararlarda herkesin fikri } \\
\text { alınmalıdır. }\end{array}$ \\
\hline
\end{tabular}

Tablo 8'de görüldüğü üzere, öğretmenlerin okulda olumlu iklim oluşturması için iletişim ve işbirliğini nasıl sağlaması gerektiğine yönelik görüşleri iletişim ve işbirliği alt temalarında belirtilmiştir. Öğretmenlerin görüşleri doğrultusunda, iletişimin; konuşarak, anlayışla, her düşünce ve fikre saygı duyularak sağlanmalı, ihtiyaçlar, gereksinimler, sorunlar rahatça konuşulup çözülmeli, empati-karşılıklı anlayış, sevgi ve sayg1 çerçevesinde, yardımlaşma ve paylaşmayla sağlanması gerektiği, alınan her türlü kararda birbirlerine saygı duyulması gerektiği, yenilikçi fikirlere açık olunmalı, öğrenci-öğretmen ve veli arasında iletişimin sağlam olması gerektiği vurgulanmıştır. İşbirliğinin ise; yaratıcı ve eğitimi destekleyici bir işbirliği içinde olunması gerektiği, öğretmenler arasında sosyal etkinlik ve sosyal faaliyetlerin sürekli düzenlenmesi gerektiği, yapılan toplantılarda, özel günlerde bir arada olunmalı ve alınan kararlarda herkesin fikri alınması gerektiği vurgulanmıştır.

Öğretmenler ile yapılan görüşmeden elde edilen verilerin analizi sonucunda öğretmenlerin okulda olumlu iklim oluşabilmesi müdürlerle ya da öğrencilerle ilişkisinin nasıl olması gerektiği konusundaki görüşleri tablo 9'da verilmiştir.

Tablo 9

Öğretmenlerin Okuldaolumlu İklim Oluşabilmesi Müdürlerle ya da Öğrencilerle İlişsisinin Nasıl Olması Gerektiğine Yönelik Görüşleri

\begin{tabular}{|c|c|}
\hline Alt Temalar & Kodlar \\
\hline \multirow{10}{*}{$\begin{array}{l}\text { Öğretmen-müdür } \\
\text { ilişsisi }\end{array}$} & Öğretmen-müdür iliskisi birbirini dinleyen, sağlıklı, iletișim odaklı bir ilisski kurulmalıdır. \\
\hline & Öncelikle kurallar iyi belirlenmeli ve hoşgörü temelli olmalıdır. \\
\hline & Müdür öğretmen ilişkisi daha samimi, anlayışlı olmalıdır. \\
\hline & Statüyü kullanmaksızın saygı ve sevgi çerçevesi içerisinde olmalıdır. \\
\hline & Mevzuatlara uygun olmalıdır. Karşılıklı, insani ve vicdani ilişkiler olmalıdır. \\
\hline & Müdür öğretmen ilişkisi resmi olması gereken durumlarda resmi, samimi olması gereken \\
\hline & $\begin{array}{l}\text { Müdür ve öğretmen görevini gerçekten iyi yapmalı, herkese eşit koşullarda } \\
\text { davranmalıdır. }\end{array}$ \\
\hline & Müdür tüm paydaşlara liderlik etmelidir. \\
\hline & Müdür öğretmen ilişkisi demokratik kurallar çerçevesinde olmalıdır. \\
\hline & İlgili tüm paydaşlar görevini doğru ve layığıyla yapmalıdır. \\
\hline \multirow{7}{*}{$\begin{array}{l}\text { Öğretmen-öğrenci } \\
\text { ilişkisi }\end{array}$} & Öğretmen-öğrenci ilişkisi saygı, sevgi ve anlayış çerçevesinde olmalıdır. \\
\hline & Öğretmen-öğrenci ilişkisi daha içli dışlı ve alakalı olmalıdır. \\
\hline & Öğretmen öğrenci ilişkisi işbirliği içinde olmalıdır. \\
\hline & Birbirlerine karşı olumlu davranışlar içinde olabilmelidir. \\
\hline & Öğretmen öğrenci ilişkisinde disiplin göz ardı edilmemelidir. \\
\hline & $\begin{array}{l}\text { Öğretmen sorumluluklarını bilmeli öğrenci ise görev ve sorumluluklarının farkında } \\
\text { olmalıdır. }\end{array}$ \\
\hline & $\begin{array}{l}\text { Öğretmen her an örnek davranış gelişimi içinde olmalıdır. Öğrenci ise öğretmenine karşı } \\
\text { saygılı olmalıdır. }\end{array}$ \\
\hline
\end{tabular}


Tablo 9'da belirtildiği üzere, öğretmenlerin okulda olumlu iklim oluşabilmesi için müdürlerle ya da öğrencilerle ilişkisinin nasıl olması gerektiğine yönelik görüş̧leri 2 alt temada vurgulanmıştır. Öğretmenlerin görüşleri doğrultusunda, müdür öğretmen ilişkisinin birbirini dinleyen, sağlıklı, hoşgörülü, anlayışlı ve daha samimi, iletişim odaklı bir ilişki içinde kurulması gerektiği, insani ve vicdani ilişkilerin sağlam olması gerektiği, kurallar iyi belirlenmeli, herkese eşit koşullarda davranılmalı, tüm paydaşlara liderlik edilmeli, demokratik kurallar çerçevesinde olmalı ve ilgili tüm paydaşlarla görevini doğru ve layığıyla yapması gerektiği belirtilmiştir. Öğretmen öğrenci ilişkisinin ise, saygı, sevgi ve anlayış çerçevesinde olmalı, daha içli dışlı ve alakalı olunmalı, öğrencilerle işbirliği içinde olunmalı, birbirlerine karşı olumlu davranışlar içinde olunmalı, disiplin göz ardı edilmemeli, öğretmen ve öğrenciler görev ve sorumluluklarının farkında olması gerektiği vurgulanmıştır.

\section{Sonuç, Tartıșma ve Öneriler}

$\mathrm{Bu}$ çalışmada öğretmenlerin okul ikliminde yer alan faktörlerin cinsiyet değişkenine göre istatistiksel olarak anlamlı düzeyde bir farklılık göstermediği sonucuna ulaşılmıştır. Ancak öğretmenlerin okul ikliminin bu çalışmada yer alan faktörlerinin öğretmenlerin görev yaptığ kademeye göre tüm faktörlerde istatistiksel olarak anlamlı düzeyde bir farkl1lık olduğu belirlenmiştir. Öğretmenlerin okul ikliminin bu çalışmada yer alan bazı faktörlerinin öğretmenlerin kıdemlerine göre istatistiksel olarak anlamlı düzeyde bir farklılık olduğu saptanırken, çatışma faktöründe ise öğretmenlerin kıdemlerine göre anlamlı düzeyde bir farklılık olmadı̆̆ incelendiğinde, Zeytin'e (2008) göre, öğretmen algılarının ilköğretim okullarındaki okul kültürüne ilişkin mesleki kıdem değişkenine göre anlamlı düzeyde bir fark bulunmazken, cinsiyet değişkenine göre anlamlı düzeyde bir fark saptanmıştır. Demir'e (2008) göre, öğretmenlerin okul ikliminin cinsiyet değişkenine göre anlamlı düzeyde bir fark bulunmuştur.

$\mathrm{Bu}$ çalışmada öğretmenlerin olumlu okul ikliminin oluşmasında; olumlu bir ortamın oluşmasının sağlanmasında, ortak hedef, ortak davranış kültürünün pekiştirilmesine, akademik başarıya doğrudan katkı sağladığına, çalışan paydaşlar arasında etkili iletişim sağladığına, motivasyonu artırdığına, derse olan verimliliği artırdığına, olumlu yönde davranış geliştirilmesine katk1 sağladığ1 sonucuna ulaşılmıştır. Bu araştırmada öğretmenlerin olumlu okul ikliminde önemli görüldüğü, olumlu okul iklim oluşturulmasında ve sürdürülmesinde öğretmenlerin okul içerisinde önemli roller üstlendiği söylenebilir. Ekşi’ye (2006) göre öğretmenlerin olumlu bir okul iklimine sahip okullarda akademik başarıyı vurguladıkları, bunun da öğrenciler için önemli ve erişilebilir hedeflere sahip olduğunu belirtmiştir. Bozdoğan ve Sağnak'a (2011) göre bir okulun öğrenme ikliminin kalitesinin, o okulun başarılı ya da başarısız ile ilişkili olduğunu belirtmişlerdir. Yine başka bir çalışmada Bektaş ve Nalçacı (2013), okullardaki olumlu iklimin doğrudan ve dolaylı olarak öğrenci başarısı ile ilişkili olduğunu belirtmişlerdir. Alanyazındaki bulgular bu çalışmanın bulguları ile örtüşmektedir.

$\mathrm{Bu}$ çalı̧̧madaki öğretmen görüşleri incelendiğinde, öğretmenlerin okuldaolumlu bir iklim oluşturulmasında öğretmen davranışlarının kendilerine yönelik görüşleri arasında; "Hedef ve sorumluluklarının farkında olmalı, hoşgörülü ve bilimsel gelişmelere açık olmalı, iletişim konusunda bilgi ve donanıma sahip olmalı, saydam, şeffaf ve saygınlık ilişkileri içerisinde olmalı, öğretmenler arasında karşılıklı saygı ve sevgi olmalı" yer almıştır. Öğretmenlerin öğrencilere yönelik görüşleri arasında ise, "Öğrencilerin bireysel farklılıklarını keşfetmeli, öğrencilere uygun bir dille yaklaşılmalı, öğrencilere sıcak olmalı ve agresif davranmamalı, öğrenciler ile iletişimi açık ve net olmalı, öğrencilere karşı herhangi bir olumsuz durumda saygılı olmalı, öğrencilere karşı tüm davranışları ile rol model olmalı, öğrencilere karşı demokratik ve hoşgörülü olması" sonuçlarına ulaşılmıştır. Öztürk'e (2008) göre okulda çalışan müdürlerin ve öğretmenlerin en önemli vazifelerinden biri de olumlu bir okulda olumlu bir iklim oluşturmak olduğu, olumlu ve sağlıklı bir okul ikliminin, öğretmenlerin kendi üretkenliklerini artırarak, öğrencilerin kendi akademik başarılarının yükseltilmesinde önemli katkılar sağlayacağını belirtmiştir. Alanyazından bulunan bu sonuçlar ise, bu çalışmanın bulguları ile örtüşmektedir. 
$\mathrm{Bu}$ çalışmada, öğretmenler okulda olumlu iklim oluşabilmesi için işbirliği ve iletişimin önemli olduğunu vurgulamışlardır. Okullarda olumlu iklim oluşması için iletişim ve işbirliğinin, her düşünce ve fikre saygı duyularak, ihtiyaçlar, gereksinimler, sorunlar rahatça konuşularak, empati-karşıllkklı anlayış, sevgi ve saygı çerçevesi içinde, yardımlaşarak ve paylaşılarak, öğretmen, öğrenci ve okul yöneticileri arasında sosyal etkinlik ve sosyal faaliyetlerin sürekli düzenlenerek olması gerektiği belirtilmiştir. Dolayısıyla bu işbirliği ve iletişimde öğretmenlere, öğrencilere ve okul yöneticilerine büyük bir görev düştüğü belirtilmiştir. Bu görevler arasında okul içerisinde okul yöneticisi-öğretmen ilişkisinin birbirini dinleyerek, hoşgörülü ve anlayışlı olarak sağlanması gerektiği, öğretmen-öğrenci ilişkisinin ise, birbirlerine olumlu davranışlar sergileyerek olması gerektiği vurgulanmıştır. Helvacı ve Aydoğan'a (2011) göre öğretmenlerin etkili okul özelliklerinin arasında okul iklimi ve kültürünün de yer aldığını belirtmişlerdir. Öğretmenlerin etkili okul özelliklerinde okul iklimi ve kültürünün özellikleri arasında, öğretmenlerin sınıflarında öğrencilerine yönelik disiplinli olması, öğrenci ve öğretmenlerin sınıf içerisinde mutlu ve huzurlu olması, öğretmenlerin kendileri arasında sağlıklı bir iletişime sahip olmasının gerekli olduğu belirtilmiştir. Şişman ve Turan'a (2004) göre okullarda olumlu bir öğrenme ve öğretme ortamı oluşturmada okul içerisinde yönetici, öğretmen, öğrenci ve personel ilişkisinin niteliği yani olumlu iklimin olduğu söylenebilir. Okullardaki yönetici ile öğretmen arasında, öğretmen ile öğretmen arasında ve öğrenci ile öğretmen arasındaki ilişkilerin olumlu iklimin oluşturulmasında önemli boyutlardan biri olduğu belirtilmiştir. Gregory, Cornell ve Fan'a (2009) göre, öğrencilerin olumlu okul iklimi olan okullarda okul disiplinini ve daha olumlu öğrenci ile öğretmen arasındaki ilişkiyi algıladıklarını, sonraki aşamada ise davranışsal sorunların olasılığının ve sıklığının daha az olduğunu belirtmişlerdir. $\mathrm{Bu}$ da olumlu okul ikliminde okul içindeki herkesin olumlu davranışlar sergilemesi gerektiğini ortaya koymuştur. Alanyazındaki bu sonuçlar ise, bu çalışmanın bulguları ile örtüşmektedir. Ancak Hamre ve Pianta (2001) ise yaptıkları çalışmada anaokullarında öğretmen ve öğrenci ilişkilerinin çelişkili ve olumsuz olduğu okullarda öğrencinin daha sonraki sınıflarda davranışsal ve akademik sorunlarının daha olası olacağı vurgulamıştır.

Araştırma sonuçları 1şığında aşağıdaki öneriler sunulabilir:

- Araştırmada öğretmenlerin girdikleri kademede çoğunlukla ilkokul ve ortaokul öğretmenlerinin olduğu ve lisede çalışan öğretmenlerin bu çalışmaya daha az katıldığ görülmüştür. Liselerde çalışan öğretmenler ile de hem anket yapılarak hem de görüşülerek araştırma genişletebilir.

- Okul iklimi bakış açıları ülkemizde genellikle okul müdürü ve öğretmen üzerinden değerlendirilmiştir. Öğrencilerin ya da 4. sınıf öğretmen adaylarının okul iklimi hakkında bakış açıları araştırılabilir, sonuçlar bu verilerle karşılaştırılabilir.

- Okullarda olumsuz davranış gösteren öğretmenlerin olumlu okul iklimine yönelik bakış açıları ile olumlu davranış gösteren öğretmenlerin olumlu okul iklimine yönelik bakış açılarını karşılaştırmaya yönelik de araştırmalar yapılabilir.

\section{Kaynaklar}

Akman, Y. (2010).Illköğretim ikinci kademe öğrencilerinin şiddet ve okul iklimi algıları arasındaki ilişki. Yüksek Lisans Tezi, Gazi Üniversitesi Eğitim Bilimleri Enstitüsü, Ankara.

Aytaç, T. (2000). Okul merkezli yönetim. Ankara: Nobel.

Bektaş, F. ve Nalçacı, A. (2013). Okul iklimi ile öğrenci başarısı arasındaki ilişki. Uluslararası Avrasya Sosyal Bilimler Dergisi, 4(13), 1-13.

Bradshaw, C. P., Koth, C. W., Thornton, L. A., and Leaf, P. J. (2009). Altering school climate through school-wide Positive Behavioral Interventions and Supports: findings from a grouprandomized effectiveness trial. Prev Sci, 10(2), 100-115. Doi:10.1007/s11121-008-0114-9. 
Bozdoğan, K. ve Sağnak, M. (2011). İlköğretim okulu müdürlerinin liderlik davranışları ile öğrenme iklimi arasındaki ilişki. Abant İzzet Baysal Üniversitesi, Eğitim Fakültesi Dergisi, 11(1), 137145 .

Bulach, C. R. and Malone, B. (1994). The relationship of school climate to the implementation of school reform. Ers Spectrum, 12(4), 3-8.

Büyüköztürk, Ş., Çakmak, E. K., Akgün, Ö. E., Karadeniz, Ş. ve Demirel, F. (2014). Bilimsel araştırma yöntemleri. Ankara: Pegem Akademi.

Canlı, S., Demirtaş, H. ve Özer, N. (2018). Okul iklimi ölçeğinin geçerlik ve güvenirlik çalışması. Illkögretim Online, 17(4), 1797-1811. Doi:10.17051/ilkonline.2019.506842.

Celep, C. (2001). Eğitimde örgütsel adanma ve öğretmenler. Ankara: An1.

Creswell, J. W. (2005). Educational research: Planning, conducting and evaluating quantitative and qualitative research (2nd Edition). New Jersey: Pearson Education.

Delice, A. (2015). Karma yöntem desen seçimi. İçinde Dede Y. ve Demir S. B. (Eds.), Karma yöntem araştırmaları tasarımı ve yürütülmesi (ss. 61-116). Ankara: An1.

Demir, A. (2008). Ortä̈gretim okullarında okul iklimi ile ögretmen performansları arasındaki ilişki. Yüksek Lisans Tezi, Yeditepe Üniversitesi Sosyal Bilimler Enstitüsü, İstanbul.

Durmuş, E., Aypay, A. ve Aybek, E. C. (2017). Parental monitoring and positive school climate in preventing school burnout. Kuram ve Uygulamada Eğitim Yönetimi, 23(3), 355-386. Doi: 10.14527/kuey.2017.013.

Duran, E. ve Erkek, G. (2018). Ortaokul 8. sınıf öğrencilerinin okuma ön yargılarının belirlenmesi, Ahi Evran Üniversitesi Sosyal Bilimler Enstitüsü Dergisi, 4(1), 1-17. Doi: 10.31592/aeusbed.368064.

Ekşi, F. (2006). Rehber ögretmenlerin okul iklimi algıları ile kaygı düzeyleri arasındaki ilişsi üzerine bir araştırma. Yüksek Lisans Tezi, Marmara Üniversitesi, Eğitim Bilimleri Enstitüsü, İstanbul.

Ellis, T. I. (1988). School climate. Research Roundup, 4(2), 1-6.

Eurydice. (2019). Levels of autonomy and responsibilities of teachers in Europe. http://eacea.ec.europa.eu/education/eurydice/documents/thematic_reports/094EN.pdf adresinden 20.11.2019 tarihinde erişilmiştir.

Freiberg, H. J. (1998). Measuring school climate: Let me count the ways. Educational Leadership, 56(1), 22-26.

Gonder, P. O. and Hymes, D. (1994). Improving school climate \& culture. Arlington, VA: American Association of School Administrators.

Gray, C., Wilcox, G. and Nordstokke, D. (2017). Teacher mental health, school climate, inclusive education and student learning: A review. Canadian Psychology/Psychologie canadienne, 58(3), 203-210. Doi:10.1037/cap0000117. 
Helvacı, M. A. ve Aydoğan, İ. (2011). Etkili okul ve etkili okul müdürüne ilişkin öğretmen görüşleri. Uşak Üniversitesi Sosyal Bilimler Dergisi, 4(2), 41-60.

Hirase, S. K. (2000). School climate. Doctorate dissertation, The University of Utah, USA.

Hoy, W. K., Tarter, T. J. and Kottkamp, R. B. (1991). Open schools/healthy schools: Measuring organisational climate. London: Sage.

Özdemir, S., Sezgin, F., Şirin, H., Karip, E. ve Erkan, S. (2010). İlköğretim okul öğrencilerinin okul iklimine ilişkin algılarını yordayan değişkenlerin incelenmesi. Hacettepe Üniversitesi Ĕgitim Fakültesi Dergisi, 38(38), 213-224.

Öztürk, E. (2008). Illköğretim okullarında görev yapan okul yöneticilerinin vizyoner liderlik özelliklerine sahip olmaları ve okul iklimi arasındaki ilişki (Edirne ili örneği).Yüksek Lisans Tezi, Çanakkale Onsekiz Mart Üniversitesi Sosyal Bilimler Enstitüsü, Çanakkale.

Shapiro, E. S., Dupaul, G. J., Bradley, K. L. and Bailey, L. T. (1996). A school-based consultation program for service delivery to middle school students with attention-deficit/hyperactivity disorder. Journal of Emotional and Behavioral Disorders, 4(2), 73-81.

Sweetland, S. R. and Hoy, W. K. (2000). School characteristics \&educational outcomes: Toward an organizational model of student a chievement in middle schools. Educational Administration Quarterly, 36(5), 703-729.

Şenel, T. ve Buluç, B. (2016). İlkokullarda okul iklimi ile okul etkililiği arasındaki ilişki. TÜBAV Bilim, 9(4), 1-12.

Şişman, M. ve Turan, S. (2004). Eğitim ve okul yönetimi. İçinde Özden Y. (Ed.), Eğitim ve okul yöneticiliği el kitabl (ss. 99-159). Ankara: Pegem A.

Thapa, A., Cohen, J., Guffey, S. and Higgins-D'Alessandro, A. (2013). A review of school climate research. Review of Educational Research, 83(3), 357-385.

Thomas, A. R. (1976). The organizational climate of schools. International Review of Education, 22(4), 441-463.

Wang, M. T. and Degol, J. L. (2016). School climate: A review of the con-struct, measurement, and impact on student outcomes. Educational Psychology Review, 28, 315-352. Doi:10.1007/s10648-015-9319-1.

Way, N., Reddy, R. and Rhodes, J. (2007). Students' perceptions of school climate during the middle school years: associations with trajectories of psychological and behavioral adjustment. American Journal of Community Psychology, 40, 194-213.

Wei, L. T. (2003). Organizational climate and effectiveness in junior-middle school in P. R. China. Masters' thesis, University of Regina, China.

Yılmaz, K. ve Altınkurt, Y. (2013). Örgütsel iklim ölçeğinin Türkçeye uyarlanması: Geçerlik ve güvenirlik çalışması. Trakya Üniversitesi Eğitim Fakültesi Dergisi,3(1), 1-11. 
Zeytin, N. (2008). Illköğretim okullarında bürokratikleşme ve okul kültürü. Yüksek Lisans Tezi, Dokuz Eylül Üniversitesi Eğitim Bilimleri Enstitüsü, İzmir.

Zullig, K. J., Koopman, T. M., Patton, J. M. and Ubbes, V. A. (2010). School climate: Historical review, instrument development, and school assessment. Journal of Psychoeducational Assessment, 28(2), 139-152. 


\section{Extended Abstract}

\section{Introduction}

Expectations in schools have reached a higher level associated with the needs in the society increased. Many of these expectations have led to a significantly change in the teaching profession as far as previous years. Responsibilities given to teachers have increased gradually in recent years. The fact that teachers assumed these responsibilities required them to act autonomously, to have a voice more in their educational processes and to take more responsibility (Eurydice, 2019).

Administrator, teacher, student and staff feel that they are individually valuable themselves in a positive school climate. School members at school successfully contribute to creating a positive climate. In addition, there are opportunities for relevance, social development, in the school solidarity, communication, academic development and participation in the formation of this climatethe members of the school (Gonder \& Hymes, 1994). Some of the behaviors that play a role in creating a positive climate at school are also that individuals in the school trust each other, the teachers are committed to work, they work cooperatively, teachers' mutual respect and help each other, teachers and administrators support each other(Ellis, 1988).

The support of teachers in creating a positive school climate is any a undeniable fact. School climate has a great impact on teachers 'performance as it positively affects teachers' motivation. The relationships between teachers, managers and colleagues play an important role in shaping their behavior and motivation which is lesson (Hirase, 2000). Teachers play an important role in creating a positive school climate, but the barrier of daily stress and demands applied can hinder this process. In order for teachers to meet their colleagues, it is necessary to solve their problems. Teachers need support and time from the school administration to attend skill development workshops. Support group sessions can help teachers learn new skills and practice them in the classroom (Shapiro, Dupaul, Bradley, and Bailey, 1996). Some behaviors of teachers in the schools, reward and punishment systems, structure of the working group in the school constitutes the elements that determine the cultural structure of the school (Celep, 2001).

It has been observed that teachers have a great job in schools but it was observed that teachers do not have a common view and also have difficulties in creating a positive climate in schools. Therefore, the aim of this research is reveal perspectives about positive school climate in the school which teachers job work. For this reason, the answers to the following questions were sought in this study:

1. Do teachers' aspects related to positive school climate differ significantly by gender?

2. Do teachers' aspects related to positive school climate differ significantly by grade?

3. Do teachers' aspectsrelated to positive school climate differ significantly by seniority?

4. What are the opinions of teachers about the positive school climate?

\section{Method}

Exploratory sequential pattern, one of the mixed method patterns, was used in the study. The study group of the research consists of 107 teachers working in primary, secondary and high schools in Kırşehir city center in the 2019-2020 academic year. In the quantitative dimension of the research, the "School Climate Scale" developed by Canll, Demirtaş and Özer (2018) was applied, and in the qualitative dimension of the research, data was provided to collect with a semi-structured interview form developed by the researchers. T-test for independent groups in determining the difference according to the gender variable of the scores obtained from the scale and One-way analysis of variance (ANOVA) was performed to determine of the difference according to the grade and seniority entered of teachers. 


\section{Result, Discussion and Conclusions}

In this study, it was concluded that the factors included in the school climate scale of the teachers did not show a statistically significant difference according to the gender variable. However, it was determined that there was a statistically significant difference in all factors according to the grade of that teacher work factors which take part in the school climate scale.

In this study, it emphasized that teachers emphasized the importance of cooperation and communication in order to create a positive climate in school. In order to establish a positive climate in schools of teachers, communication and cooperation is by respected every thought and idea; by requirement, needs, problems can be spoken easily; by helping and sharing within the framework of empathy-mutual understanding, love and respect; it was stated that social activities and social actions should be by continuous organized among teachers, students and school administrators.

In this study, in the formation of positive school climate of teachers; the result has been reached which it is create a positive environment; common goal, common behavior the culture is reinforced; contributes directly to academic success; ensure effective communication among working stakeholders; increase motivation; increase the efficiency of the lesson; contributes to positive behavior development. In this study, it can be said that teachers are considered important in a positive school climate, and teachers play an important role within school in creating and maintaining a positive school climate. According to Ekşi (2006), teachers stated that they emphasize academic success in schools with a positive school climate, and this has important and accessible goals for students. According to Bozdoğan and Sağnak (2011), they stated that the quality of a school's learning climate is related to the success or failure of that school. In another study, Bektaş and Nalçacı (2013) stated that the positive climate in schools is directly and indirectly related to student success. Findings in the literature overlap with the findings of this study.

In the research, it was observed that there are mostly primary and secondary school teachers at the grade entered by teachers and teachers working in high school participated less in this study. It can also expand research both conducting surveys and talking with teachers working in high schools. 